\title{
Responses of Amaranthus hybridus to effluent from an aluminum plating industry in Lagos, Nigeria
}

\author{
V. J. Odjegba ${ }^{1}$ B. D. Oyenekan ${ }^{1}$ \\ ${ }^{1}$ Department of Botany, University of Lagos, Akoka, Lagos, Nigeria
}

Received: 11 August 2015/Revised: 21 December 2015/Accepted: 6 January 2016/Published online: 17 February 2016 (c) Joint Center on Global Change and Earth System Science of the University of Maryland and Beijing Normal University and Springer-Verlag Berlin Heidelberg 2016

\begin{abstract}
The study investigated the responses of Amaranthus hybridus to effluent from an aluminum plating plant in Lagos, Nigeria. Seedlings were raised from seeds and were grouped into three categories, each representing a treatment. The first group which is the control received $250 \mathrm{ml}$ of water via the roots every 3 days, the second category received half-strength effluent via the roots every 3 days, while the third group received full-strength effluent via the roots every 3 days throughout the study period. Physiological and biochemical, as well as metabolic, parameters representative of oxidative damage and antioxidant activity were evaluated after the treatments. The physicochemical analysis of the effluent showed that total suspended solids, $\mathrm{Al}$ and $\mathrm{Zn}$ levels were higher than the recommended standards. The biomass and the protein content of the control were $18.01 \mathrm{~g}$ and $0.835 \mathrm{mg} / \mathrm{g}$ dry wt, respectively, as against $12.04 \mathrm{~g}$ and $0.368 \mathrm{mg} / \mathrm{g}$ dry wt observed in the treated plants. In contrast, effluent treatment caused a significant increase in malondialdehyde level as well as activities of antioxidant enzymes. The present study revealed that the effluent adversely affected growth and development of A. hybridus. Continual discharge of these industrial effluents could have a negative impact on the environment especially to fragile ecosystems.
\end{abstract}

Keywords Amaranthus hybridus $\cdot$ Environment $\cdot$ Growth inhibition · Industrial effluent · Toxicity

V. J. Odjegba

jodjegba@unilag.edu.ng

\section{Introduction}

Environmental pollution caused by effluents emanating from industrial firms is now a growing concern in many countries of the world due to a number of harmful substances contained in them and their potential health effects. These industries generate wastewater of diverse chemical composition, which when discharged could lead to drastic changes in both biological and chemical parameters of the receiving ecosystem (Gomez et al. 2008).

To minimize impacts on ecosystems, it is important to treat effluents before discharge into the environment. Although authorities of different countries have extant laws that mandate every industry to treat their wastewaters before discharge into the environment, studies have shown that analysis of effluent indicates the presence of chemical substances capable of causing harm to the living organisms (Radic et al. 2010). In some cases, the treated effluent does not exceed the discharge limits but the results of toxicity test shows potential toxicity (Lin et al. 1994).

Industrial effluents are generally decontaminated by physicochemical treatment, where pollutants are insolubilized, thereby generating two phases: water and sludge which are subsequently separated by a physical process (Charles et al. 2011). It is now known that chemical precipitation does not remove the whole pollutant load, and their impacts on the natural environment are difficult to forecast (Kumari and Tripathi 2015). The presence of toxic pollutants can be detected by the changes caused in an organism with the use of bioassays (Valerio et al. 2007; Di Salvatore et al. 2008). In particular, the phytotoxicity tests using plants present several advantages. First, these tests are simple, quick and reliable. Second, 
they are inexpensive and do not require sophisticated equipment. Third, plants can be more sensitive to environmental stress than other organisms (Gopalan, 1999; Valerio et al. 2007).

Higher plant toxicity assays, including Allium cepa, Vicia faba, Arabidopsis thaliana, Hordeum vulgare, Triticum aestivum, Zea mays, Lactuca sativa, have been calibrated with a broad range of chemicals (Yi and Meng 2003; $\mathrm{Ma}$ et al. 2005). Since higher plant systems have unique advantages for in vitro monitoring and screening (Ma et al. 2005), it is recommended that higher plant systems should be accepted by regulatory authorities as first-tier assay system for detecting the possible biotoxicity associated with environmental stress (Han et al. 2011).

In Nigeria, environmental regulations on pollution control of industrial discharges and other pollutants are enforced by the National Environmental Standards and Regulations Enforcement Agency (NESREA) which relies on conventional physicochemical procedures. Lagos is a highly populated metropolitan city with quite a number of industries, a development that has put the city under serious pressure in terms of environmental safety. Consequently, the city and its environs have witnessed environmental degradation leading to decreased biodiversity and extinction of many sensitive organisms. Pollution of the environment with effluents from various industries has become a serious problem in Lagos, as industrial growth and development has been on the increase in the last 10 years. Pharmaceutical, agroallied, aluminum plating, plastic, chemical and food industries, etc., are located in different parts of the city. Due to the nature of their operations which requires large volume of water, most of the effluents generated are discharged into the environment, thereby altering its natural state in terms of quality.

The ecological and toxicological problems resulting from the discharge of effluents from the aluminum plating industry under review has been the most important water pollution problems in this area. This problem is further aggravated because some residents along the stream axis depend directly on this stream as source of portable water and other domestic purposes. In addition, local farmers, particularly vegetable growers, use the water from this stream directly for irrigation purposes. Consequently, there is likelihood that toxicants from this effluent may affect plants and animals, enter the food chain and affect a larger human population. Therefore, this work aimed to evaluate the toxicity of discharged effluent from an aluminum plating industry using A. hybridus as a model plant. The plant is a popular leafy vegetable cultivated in domestic gardens and consumed largely by the people in Lagos, Nigeria.

\section{Materials and methods}

\subsection{Plant Growth and Treatment}

Effluent was collected from the discharge point of the industry $\left(06^{\circ} 36^{\prime} 25^{\prime \prime} \mathrm{N}, 05^{\circ} 18^{\prime} 39.8^{\prime \prime} \mathrm{E}\right.$ and $06^{\circ} 36^{\prime} 43^{\prime \prime} \mathrm{N}$, $\left.03^{\circ} 18^{\prime} 66^{\prime \prime} \mathrm{E}\right)$ that flows into a drainage canal that connects to a river. The physicochemical parameters of the collected sample were determined in its crude natural state within $6 \mathrm{~h}$ of collection.

Seeds of A. hybridus were germinated and nursed on a nursery bed $(3 \mathrm{~m} \times 1.2 \mathrm{~m})$ for 3 weeks. Thereafter, healthy seedlings of $15 \mathrm{~cm}$ in height were transplanted into polythene bags filled with loamy soil to achieve plant stand of one seedling per bag. They were arranged in rows in a screen house at the Botanical Garden, University of Lagos $\left(06^{\circ} 31^{\prime} 4.8^{\prime \prime} \mathrm{N}, 03^{\circ} 24^{\prime} 2.18^{\prime \prime} \mathrm{E}\right.$ and $\left.06^{\circ} 31.08^{\prime} \mathrm{N}, 03^{\circ} 24.04^{\prime} \mathrm{E}\right)$. Seedlings were kept moist by watering when necessary and were allowed to acclimatize for 5 days before they were subjected to industrial effluent treatment for 3 weeks. The plants were grouped into 3 categories, each representing a treatment and replicated 12 times. Category 1 served as the control and received $300 \mathrm{ml}$ of water every 3 days throughout the experiment period, category 2 received $300 \mathrm{ml}$ of half-strength effluent every 3 days, while the third category was subjected to $300 \mathrm{ml}$ of full-strength effluent every 3 days. Plants were harvested 14 and 21 days after the initial treatment for dry weight analysis to generate data for the relative growth rate (RGR) determination and 21 days for every other analysis.

\subsection{Dry weight determination}

Plants were uprooted carefully and washed thoroughly in a running tap water to remove soil particles. After rinsing with distilled water, they were placed in labeled paper bags and oven-dried at $65{ }^{\circ} \mathrm{C}$ for $72 \mathrm{~h}$. The dried samples were weighed using a digital top loading weighing balance (Mettler AE 100) to determine the dry weight (Guo et al. 2010).

\subsection{Relative growth rate (RGR)}

The RGR of the plants was determined according to method described by Causton (1994) using the relationship:

$\mathrm{RGR}=\frac{\ln W_{2}-\ln W_{1}}{t_{2}-t_{1}} \quad \mathrm{gg}^{-1} \mathrm{wk}^{-1}$

\subsection{Relative water content (RWC)}

The fourth leaf from the apex of plants representing each treatment was harvested and weighed to determine their 
fresh weight (Fr. wt). The leaves were then submerged separately in distilled water for $24 \mathrm{~h}$ in the dark. They were removed from the water, mopped dry using an absorbent and weighed to determine their saturated weight $(\mathrm{SW})$. The leaves were then placed in labeled envelopes and dried in an oven at $65{ }^{\circ} \mathrm{C}$ for 3 days to determine the dry weight. The relative water content was calculated according to Turner (1981) using the formula: $\mathrm{RWC}=[($ fresh weight - dry weight)/(saturated weight - dry weight) $] \times 100$.

\subsection{Total chlorophyll determination}

Plant leaves $(0.3 \mathrm{~g})$ were ground in $10 \mathrm{ml} 80 \%$ acetone in the dark. After centrifugation at $18{ }^{\circ} \mathrm{C}, 4000 \times g$ for $3 \mathrm{~min}$, the absorbance of the supernatant was read at 645 and $663 \mathrm{~nm}$ (Arnon, 1949). The total chlorophyll content was calculated according to Machlachlan and Zalik (1963).

\subsection{Lipid peroxidation assay}

Lipid peroxidation was measured by estimation of the malondialdehyde (MDA) content following the procedure described by Wang and Jin (2005).

\subsection{Protein determination}

The protein level was determined by using micro-Kjeldahl method for the estimation of total organic nitrogen in the dried plant samples as described by Piorreck et al. (1984). The total nitrogen content was multiplied by 6.25 to obtain the protein concentration.

\subsection{Antioxidant enzyme assays}

Fresh leaves $(0.3 \mathrm{~g})$ were ground in $2 \mathrm{ml}$ ice-cold extraction buffer containing $50 \mathrm{mM}$ Tris- $\mathrm{HCl}(\mathrm{pH} 7.8), 1 \mathrm{mM}$ EDTA and $2 \%(\mathrm{w} / \mathrm{w})$ polyvinylpyrrolidone. The homogenate was centrifuged at $10,000 \times g$ for $8 \mathrm{~min}$, and the supernatant was used as crude extract for catalase (CAT) determination. CAT activity was determined by measuring the consumption of $\mathrm{H}_{2} \mathrm{O}_{2}$ in $2 \mathrm{ml}$ reaction mixture $(50 \mathrm{mM}$ potassium phosphate buffer, $1 \% \mathrm{H}_{2} \mathrm{O}_{2}$ and $50 \mu \mathrm{l}$ crude extract). $\mathrm{H}_{2} \mathrm{O}_{2}$ consumption was monitored for $1.5 \mathrm{~min}$ as the decrease in absorbance at $240 \mathrm{~nm}$ according to Aebi (1984). For ascorbate peroxidase (APX), fresh leaves $(0.3 \mathrm{~g})$ were homogenized in $2 \mathrm{ml}$ ice-cold extraction buffer containing $50 \mathrm{mM}$ phosphate buffer solution $(\mathrm{pH}$ 7.8 ), $2 \mathrm{mM}$ ascorbic acid and $5 \mathrm{mM}$ EDTA. After centrifugation, the supernatant was used as the crude extract for assay of APX activities following the method described by Nakano et al. (2000).

\subsection{Statistical analysis}

Data were subjected to statistical analysis using SPSS version 16.0 statistical package (SPSS, Chicago, IL). Means of three replicates as well as the standard error (SE) were determined. The test of significance between the treatments was done using a one-way analysis of variance (ANOVA).

\section{Results}

\subsection{Physicochemical characteristics of the effluent}

Table 1 depicts the physicochemical variables of the effluent as well as the recommended limits by the regulatory authority in Nigeria. The effluent's TSS and Zn levels were significantly $(p=0.05)$ higher than the reference standards, while the $\mathrm{Al}$ concentration in the effluent was higher than the recommended standard but not statistically significant. The concentrations of TSS and $\mathrm{Zn}$ in the effluent were 42 and $9.44 \mathrm{mg} / \mathrm{l}$, respectively, as against $40 \mathrm{mg} / \mathrm{l}$ and $<1$ standard limits, respectively. The concentration of $\mathrm{Al}$ in the effluent was $3.29 \mathrm{mg} / \mathrm{l}$, a value that is above the recommended discharge limit of $3.00 \mathrm{mg} / \mathrm{l}$.

Table 1 Physicochemical characterization of the effluent from aluminum plating industry in Lagos, Nigeria

\begin{tabular}{|c|c|c|c|}
\hline $\mathrm{S} / \mathrm{N}$ & Parameters & $\begin{array}{l}\text { Values } \\
\text { detected }\end{array}$ & $\begin{array}{l}\text { NESREA } \\
\text { standard limits }\end{array}$ \\
\hline 1. & $\mathrm{Ph}$ & 8.77 & $6-9$ \\
\hline 2. & Conductivity $\left(\mu \mathrm{sm}^{-1}\right)$ & 562 & 7000 \\
\hline 3. & TDS & 375 & 2000 \\
\hline 4. & TSS & 42 & 40 \\
\hline 5. & Turbidity (FTU) & 68 & - \\
\hline 6. & $\mathrm{Cl}^{-}$ & 24 & 600 \\
\hline 7. & $\mathrm{CN}^{-}$ & 0.05 & 0.1 \\
\hline 8. & $\mathrm{NO}_{3}^{-}$ & 5.48 & 20 \\
\hline 9. & $\mathrm{SO}_{4}^{2-}$ & 8.0 & 500 \\
\hline 10. & $\mathrm{NH}_{4}^{+}$ & 0.16 & 0.6 \\
\hline 11. & COD & 45 & 200 \\
\hline 12. & $\mathrm{BOD}_{5}^{20}$ & 18 & 30 \\
\hline 13. & $\mathrm{Al}$ & 3.29 & 3 \\
\hline 14. & $\mathrm{Cr}$ & 0.03 & $<1$ \\
\hline 15. & $\mathrm{Cu}$ & 0.56 & $<1$ \\
\hline 16. & $\mathrm{Ni}$ & 0.02 & $<1$ \\
\hline 17. & $\mathrm{~Pb}$ & 0.3 & $<1$ \\
\hline 18. & $\mathrm{Zn}$ & 9.44 & $<1$ \\
\hline
\end{tabular}

All units are in $\mathrm{mg} / \mathrm{L}$, except for $\mathrm{pH}$ and where noted otherwise 


\subsection{Effect of effluent on plant growth and biochemical characteristics}

The biomass of $A$. hybridus decreased significantly with increase in effluent concentration. After the treatment period, the control plants had a mean dry weight of $18.01 \mathrm{~g}$, while plants treated with 50 and $100 \%$ effluent had 16.2 and $12.04 \mathrm{~g}$, respectively (Fig. 1). The RGR of the plant was significantly reduced as the concentration increased. Plants treated with 50 and $100 \%$ effluent had mean RGR values of $1.21 \pm 0.08$ and $1.09 \pm 0.04 \mathrm{~g} \mathrm{~g}^{-1} \mathrm{wk}^{-1}$, respectively, as against $1.42 \pm 0.06 \mathrm{~g} \mathrm{~g}^{-1} \mathrm{wk}^{-1}$ observed for control (Fig. 2).

Relative water content (RWC) of leaves was higher in untreated plants, which decreased significantly with increase in effluent concentration. It was observed that the RWC for the control plants was $84.26 \%$ as against 75.25 and $58.29 \%$ in plants treated with 50 and $100 \%$ effluent, respectively (Fig. 3).

The total chlorophyll content declined gradually with increase in effluent concentration. At the end of the treatment period, the control plants had a mean value of $0.824 \pm 0.022 \mathrm{mg} \mathrm{g}^{-1}$ fr wt. This value was significantly higher than $0.734 \pm 0.026$ and $0638 \pm 0.02 \mathrm{mg} \mathrm{g}^{-1}$ fr wt

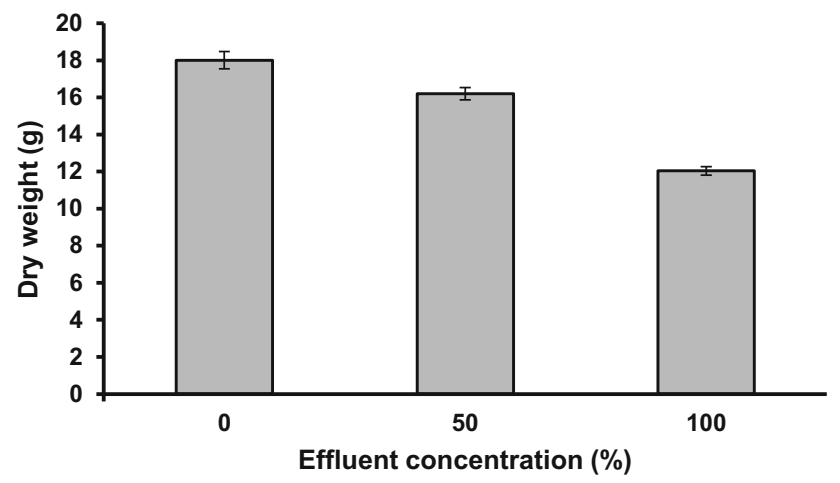

Fig. 1 Whole plant dry weight of A. hybridus treated with effluents for an aluminum plating industry

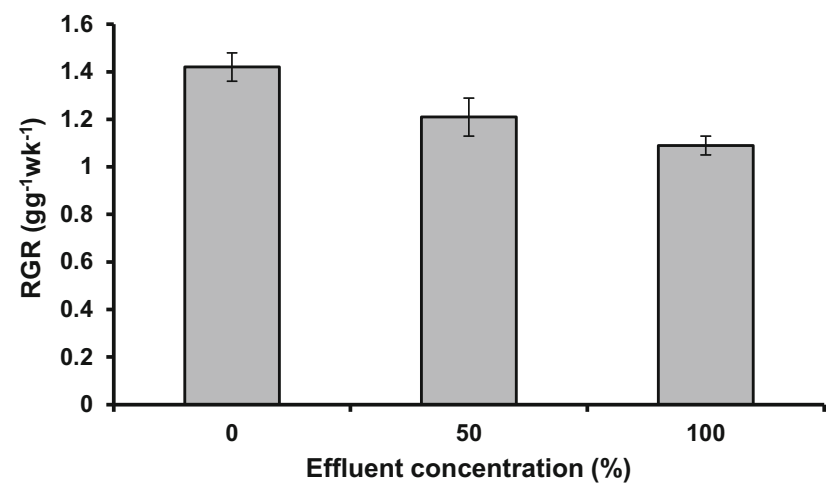

Fig. 2 Effects of effluents from aluminum plating industry on the relative growth rate (RGR) of $A$. hybridus observed for plants treated with $50 \%$ and $100 \%$ effluents, respectively (Fig. 4).

To assess the effects of the effluent on lipid peroxidation, malondialdehyde (MDA) content in the leaves of the plants was measured. Treatment of plants with 50 and $100 \%$ effluent, respectively, led to more than 16 and $70 \%$ increase in MDA content when compared to the control plants (Fig. 5).

Figure 6 depicts the effect of the industrial effluent on the protein content of A. hybridus. It was observed that the effluent significantly decreased the protein content in the treated plants. The protein content of the control plants was significantly ( $p=0.05$ ) higher than the values observed for plants exposed to the effluent. The control plants had a mean value of $0.835 \pm 0.02 \mathrm{mg} \mathrm{g}^{-1}$ dry wt, compared to $0.579 \pm 0.04$ and $0.368 \pm 0.04 \mathrm{mg} \mathrm{g}^{-1}$ dry wt observed for plants treated with 50 and $100 \%$ effluent, respectively.

It was observed that the effluent induced a strong antioxidative response in A. hybridus as evident in the assessment of CAT and APX activities in both the treated and the untreated plants (Figs. 7, 8). Plants treated with $100 \%$ effluent had mean values of $28.49 \pm 1.30 \mu \mathrm{mol} \mathrm{H}_{2} \mathrm{O}_{2} \mathrm{~g}^{-1} \mathrm{fr}$ wt $\min ^{-1}$ and $0.081 \pm 0.002 \mu \mathrm{mol}$ ascorbate $\mathrm{g}^{-1}$ fr wt $\min ^{-1}$ as CAT and APX activities, respectively. These

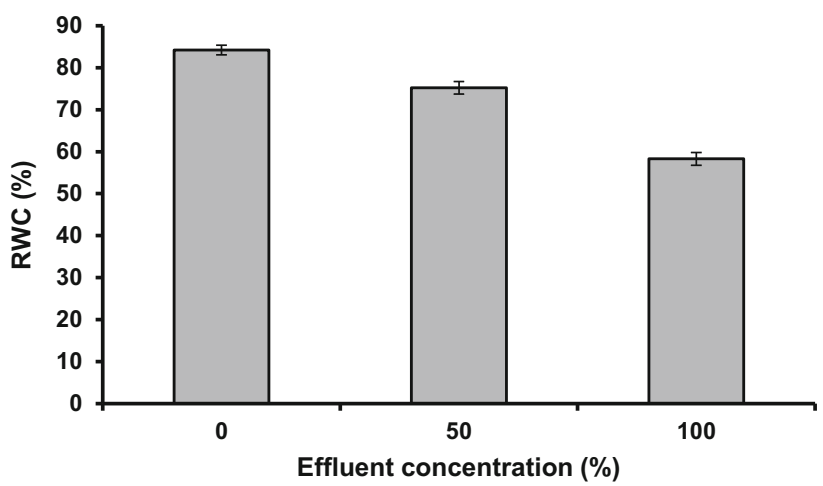

Fig. 3 Relative water content of A. hybridus leaves as affected by effluent treatments

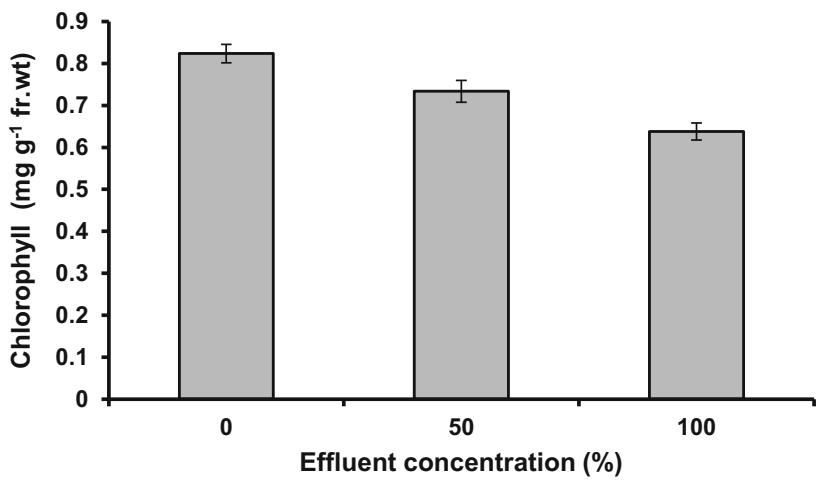

Fig. 4 Total chlorophyll content of A. hybridus after exposure to effluent from aluminum plating industry 


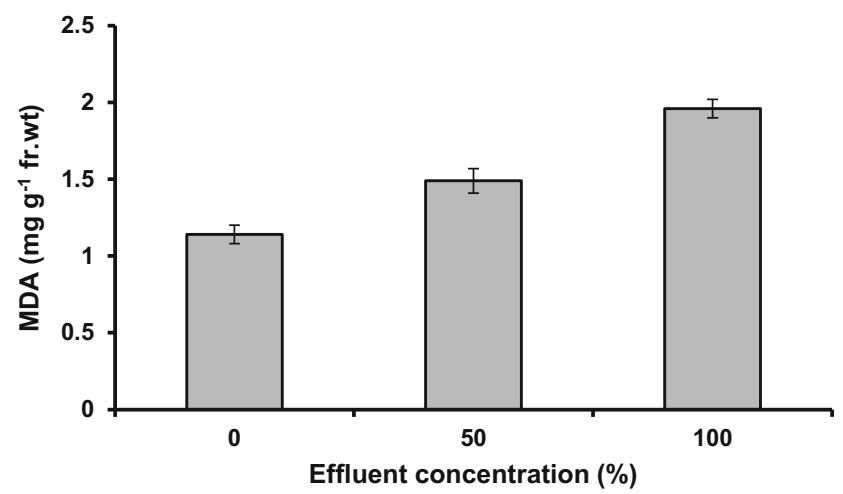

Fig. 5 Malondialdehyde content of A. hybridus as affected by effluents from aluminum plating industry

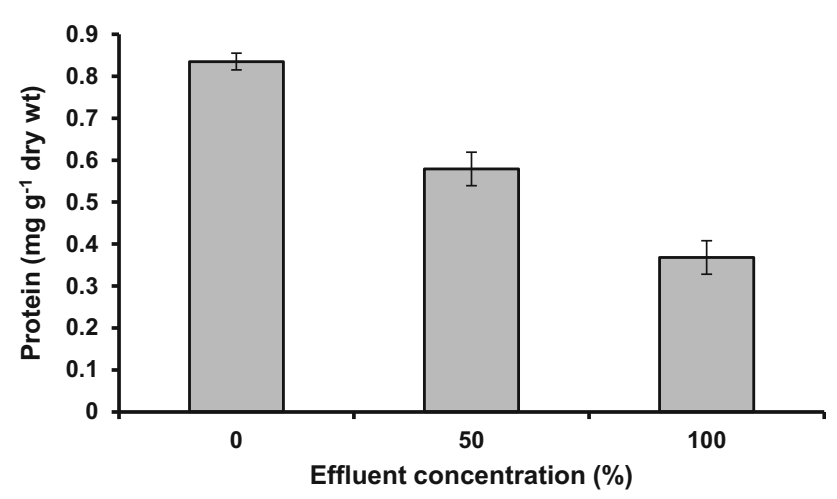

Fig. 6 Total protein content of A. hybridus after exposure to effluents from aluminum plating industry

values were significantly higher than $17.62 \pm 1.12 \mu \mathrm{mol}$ $\mathrm{H}_{2} \mathrm{O}_{2} \mathrm{~g}^{-1}$ fr wt $\min ^{-1}$ and $0.037 \pm 0.02 \mu \mathrm{mol}$ ascorbate $\mathrm{g}^{-1}$ fr wt $\min ^{-1}$ that were, respectively, observed as CAT and APX activities in the control plants.

\section{Discussion}

This study indicates that effluent from the aluminum planting industry induced oxidative stress and significantly reduced the growth, biomass and nutrients in A. hybridus seedlings. The results imply that the effluent might cause biotoxicity on living organisms. The physicochemical analysis of the effluent showed that TSS, Al and Zn exceeded the permissible limits, an indication that the conventional technology used in wastewater treatment appears to be insufficient for a complete removal of all the chemical compounds present in the effluent (Ternes 1998).

The significant decrease in whole plant biomass as well as inhibition of RGR observed for plants treated with effluent suggests bioaccumulation of pollutants, possibly heavy metals such as $\mathrm{Cu}, \mathrm{Cr}, \mathrm{Ni}$ and $\mathrm{Pb}$ present in the

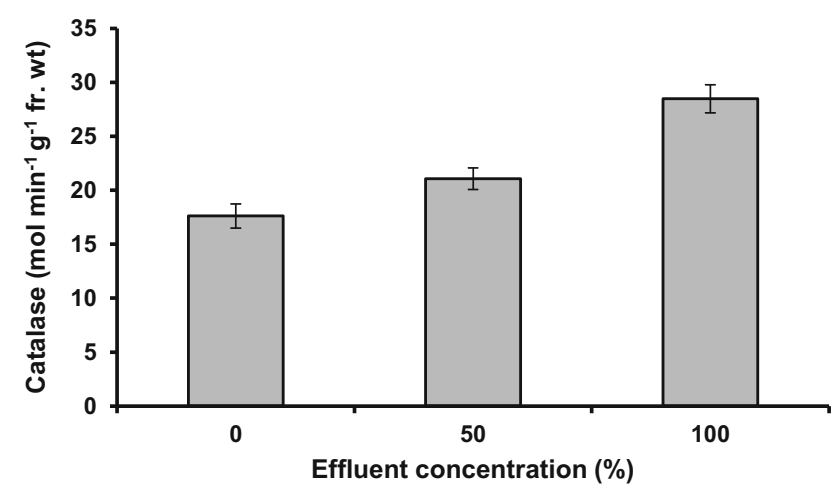

Fig. 7 Impact of effluents from aluminum plating industry on catalase activities in A. hybridus

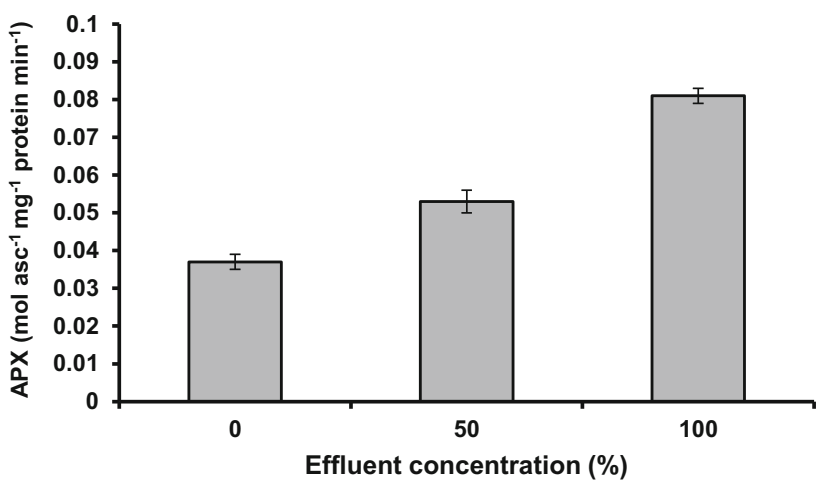

Fig. 8 Ascorbate peroxidase activities in A. hybridus after treatments with effluents from aluminum plating industry

effluent. Application of effluent to soil over a period could lead to accumulation of toxic metals as well as a change in the soil environment, such as $\mathrm{pH}$, redox potential and organic matter contents (Hossain et al. 2015). The toxicity of heavy metals appears to arise from complex interactions among different essential and non-essential elements, which may inhibit metabolic enzymes activities that could negatively affect the growth of the plant (Latif et al. 2008). The significance of different aluminum species in different environments as well as their toxicity effects has been documented (Gardner et al. 2002; Guibad and Gauthier 2003). Apart from the free $\mathrm{Al}^{3+}$ species, the highly reactive hydroxo-complexes, for instance $\mathrm{Al}(\mathrm{OH})_{2}^{+}$and $\mathrm{AlOH}^{2+}$, are quite toxic and they predominate at $\mathrm{pH}$ range 6-9 (Sacan and Balcioglu 2006).

The significant decrease in leaf relative water content (RWC) observed in plants treated with effluent could be due to increased ionic content of soil water as a result of effluent application which subsequently resulted in low water potential of the solution that consequently affected water absorption by plant roots. This observation is in conformity with the findings of Ashraf et al. (2002). 
The decline in total chlorophyll content observed in effluent-treated plants can be regarded as general responses associated with metal toxicity. The loss of photosynthetic pigment content as a result of industrial effluent treatments has been reported (Sacan and Balcioglu 2006; Radic et al. 2010; Odjegba and Bamgbose 2012). Generally, the destruction of chlorophyll by heavy metals could be due to disruption of electron transport chain, substitution of $\mathrm{Mg}^{2+}$ of the tetra-pyrrole ring of the chlorophyll molecules, inhibition of enzymes associated with chlorophyll biosynthesis or peroxidation of chloroplast membrane lipids by ROS (Van Assche and Clijsters 1990; Sandalio et al. 2001).

An important feature of metal-induced environmental stress is the activation of a common mechanism involving the production of ROS in cells of the affected organism (Shi and Zhu 2008; Wang et al. 2004). Since membrane lipid is one of the preferred targets of ROS in plant under environmental stress, it is considered to be a reliable indicator of controlled modulation of ROS levels and oxidative stress (Halliwell and Gutteridge 1999). We investigated the levels of lipid peroxidation by measuring MDA in the leaves. A. hybridus showed high level of MDA under effluent treatment. It was an indication that pollutants contained in the effluent were absorbed by the plants and induced the generation of excessive ROS; thus, the plant experienced substantial oxidative stress. Similar results were reported previously by Verma and Dubey (2003), Zhang et al. (2007) and Radic et al. (2010).

There was a significant decrease in protein content of the effluent-treated plants compared to the control. Similar results were reported by past investigators when plants were subjected to various abiotic stress factors (Osama and Floyd 1984; Caplan et al. 1990; Deepika and Dhingra 2014). The decrease in protein content in the treated plants could be related partly to the inhibition of glutamine synthetase (GS) and glutamate synthase (GOGAT) activities (Nemat Alla et al. 2008). The failure in GS-GOGAT system function would cause accumulation of unassimilated ammonia and, consequently, diminution in amino acid formation with a subsequent drop in protein synthesis.

Plants possess complex antioxidative defense system comprising of non-enzymatic and enzymatic components to scavenge ROS. Under normal conditions, potentially toxic oxygen radicals are generated at a low level and are adequately detoxified by different antioxidant enzymes present in the plant cells. The balance between production and quenching of ROS may be perturbed by a number of adverse environmental factors, giving rise to rapid increase in intracellular ROS levels (Sharma et al. 2010). In order to avoid the oxidative damage, higher plants raise the level of endogenous antioxidant defense and such response reflects an adaptation of a plant to its environment (Yordanova et al. 2004). In the present study, it was observed that the activities of catalase and ascorbate peroxidase increased significantly when A. hybridus was treated with effluent from aluminum plating industry. The increase in activity of these antioxidant enzymes as well as MDA content underscored the fact that the effluent caused oxidative stress in the plant.

\section{Conclusion}

The present investigation confirmed that the effluent from aluminum plating industry affected the growth, dry biomass, relative water content, photosynthetic pigment and protein content of A. hybridus. Hence, ecological and toxicological problems may arise from continuous discharge of effluents from the aluminum plating industry into the environment in its present form. The physicochemical analysis of the effluent showed that TSS, Al and Zn levels were higher than the recommended standards. These data indicate that effluent from this aluminum plating industry could cause toxic effects on organisms and that the treatment carried out on the effluent before discharge into the environment is not as efficient as it ought to be in removing the hazardous contaminants present in it. To this end, it is suggested that effluent from aluminum plating industries should be used with caution especially by vegetable growers for irrigation of agricultural lands.

Acknowledgments The authors are thankful to Mr B. M. Begusa of Chemistry Department, University of Lagos, for his technical support.

\section{References}

Aebi H (1984) Catalase in vitro. Methods Enzymol 105:121-126 Arnon DI (1949) Copper enzymes in isolated chloroplast, polyphenoloxidase in Beta vulgaris. Plant Physiol 24:1-15

Ashraf MY, Sarwar G, Ashraf M, Afaf R, Sattar A (2002) Salinity induced changes in $\alpha$-amylase activity during germination and early cotton seedling growth. Biol Plant 45:589-591

Caplan AB, Dekeyser CR, Van Montagu M (1990) Salinity and drought stress in rice. In: Sangwan RS, Sagwan-Norrel B (eds) The impact of biotechnology in agriculture. Kluwer Academic Publishers, Amsterdam, pp 391-404

Causton DR (1994) Plant growth analysis: a note on the variability of unit leaf rate (net assimilation rate) within a sample. Ann Bot 74:513-518

Charles J, Sancey B, Morin-Crini N, Badot P, Degiorgi I, Trunfio G, Crini G (2011) Evaluation of the phytotoxicity of polycontaminated industrial effluents using the lettuce plant (Lactuca sativa) as a bioindicator. Ecotoxicol Environ Saf 74:2057-2064

Deepika G, Dhingra HR (2014) Effect of salinity stress on morphophysiological, biochemical and yield characters of cluster bean [Cyamopsis tetragonoloba (L.) Taub.]. Ind J Plant Physiol 19(4):393-398

Di Salvatore M, Carafa AM, Carratu G (2008) Assessment of heavy metals phytotoxicity using seed germination and root elongation tests: a comparison of two growth substrates. Chemosphere 73:1461-1464 
Gardner MJ, Dixon E, Sims I, Whitehouse P (2002) Importance of speciation in aquatic toxicity tests with aluminum. Bull Environ Contam Toxicol 68:195-200

Gomez N, Sierra MV, Cortelezzi A, Capitulo AR (2008) Effects of discharges from the textile industry on the biotic integrity of benthic assemblages. Ecotoxicol Environ Saf 69:472-479

Gopalan HNB (1999) Ecosystem health and human wellbeing: the mission of the international programme plant bioassays. Mutat Res 426:99-102

Guibad G, Gauthier C (2003) Study of aluminum concentration and speciation of surface water in four catchments in the Limousin region (France). J Inorg Biochem 97:16-25

Guo J, Yang Y, Wang G, Yang L, Sun X (2010) Ecophysiological responses of Abies fabri seedlings to drought stress and nitrogen supply. Physiol Plant 139:335-347

Halliwell B, Gutteridge JMC (1999) Free radicals in biology and medicine, 3rd edn. Oxford Science Publications, New York 936 pp

Han M, Li G, Sang N, Dong Y (2011) Investigating the bio-toxicity of coking wastewater using Zea mays L. assay. Ecotoxicol Environ Saf 74(4): 1050-1056

Hossain MA, Rahman GKMM, Rahman MM, Molla AH, Rahman MM, Uddin MK (2015) Impact of industrial effluent on growth and yield of rice (Oryza sativa L.) in silty clay loam soil. J Environ Sci 30:231-240

Kumari M, Tripathi BD (2015) Efficiency of Phragmites australis and Typha latifolia for heavy metal removal from wastewater. Ecotoxicol Environ Saf 112:80-86

Latif MI, Lone MI, Khan KS (2008) Heavy metals contamination of different water sources, soils and vegetables in Rawalpindi area. Soil Environ 27(1):29-35

Lin CF, Hao OJ, Jeng FT (1994) Microtox evaluation of industrial wastewaters. Water Sci Technol 30(10):97-106

Ma TH, Cabrera GL, Owens E (2005) Genotoxic agents detected by plant bioassays. Rev Environ Health 20:1-13

Machlachlan S, Zalik S (1963) Plastid structure chlorophyll concentration and free amino acid composition of a chlorophyll mutant of barley. Can J Bot 141:1053-1062

Nakano H, Muramatsu S, Makino A, Mae T (2000) Relationship between the suppression of photosynthesis and starch accumulation in the pod-removed bean. Aus J Plant Physiol 27:167-173

Nemat Alla MM, Badawi AM, Hassan NM, El-Bastawisy ZM, Badran EG (2008) Effect of metribuzin, butachlor and chlorimuron-ethyl on amino acid and protein formation in wheat and maize seedlings. Pestic Biochem Physiol 90:8-18

Odjegba VJ, Bamgbose NM (2012) Toxicity assessment of treated effluents from a textile industry in Lagos, Nigeria. Afr J Environ Sci Technol 6(11):438-445

Osama A, Floyd MA (1984) Bentazone influence on selected metabolic processes of isolated bean leaf cells. J Plant Growth Regul 3:121-126
Piorreck M, Baasch K, Pohl P (1984) Biomass production, total protein, chlorophylls, lipids and fatty acids of freshwater green and blue-green algae under different nitrogen regimes. Phytochemistry 23:207-216

Radic S, Stipaniev D, Cvjetko P, Mikelic IL, Rajcic MM, Sirac S, Pevalek-Kozlina B, Pavlica M (2010) Ecotoxicological assessment of industrial effluent using duckweed (Lemna minor L.) as a test organism. Ecotox 19:216-222

Sacan MT, Balcioglu IA (2006) A case study on algal response to raw and treated effluents from an aluminum plating plant and a pharmaceutical plant. Ecotoxicol Environ Saf 64:234-243

Sandalio LM, Dalurzo HC, Gomez M, Romero-Puertas MC, del Rio LA (2001) Cadmium-induced changes in the growth and oxidative metabolism of pea plants. J Exp Bot 52:2115-2126

Sharma I, Pati PK, Bhardwaj R (2010) Regulation of growth and antioxidant enzyme activities by 28 -homobrassinolide in seedlings of Raphanus sativus L. under cadmium stress. Indian J Biochem Biophys 47:172-177

Shi Q, Zhu Z (2008) Effects of exogenous salicylic acid on manganese toxicity, element contents and antioxidative system in cucumber. Environ Exp Bot 63:317-326

Ternes TA (1998) Occurrence of drugs in German sewage treatment plants and rivers. Water Res 32:3245-3260

Turner NC (1981) Techniques and experimental approaches for the measurement of plant water status. Plant Soil 58:339-366

Valerio ME, Garcia JF, Peinado FM (2007) Determination of phytotoxicity of soluble elements in soils, based on a bioassay with lettuce (Lactuca sativa L.). Sci Total Environ 378:63-66

Van Assche F, Clijsters H (1990) Effects of metals on enzyme activity in plants. Plant, Cell Environ 13:195-206

Verma S, Dubey RS (2003) Lead toxicity induces lipid peroxidation and alters the activities of antioxidant enzymes in growing rice plants. Plant Sci 164:645-655

Wang H, Jin JY (2005) Photosynthetic rate, chlorophyll fluorescence parameters, and lipid peroxidation of maize leaves as affected by zinc deficiency. Photosynthetica 43:591-596

Wang YS, Wang J, Yang ZM, Wang QY, Li B, Li SQ, Lu YP, Wang SH, Sun X (2004) Salicylic acid modulates aluminum-induced oxidative stress in roots of Cassia tora. Acta Bot Sin 46:816-828

Yi HL, Meng ZQ (2003) Genotoxicity of hydrated sulfur dioxide on root tips of Allium sativum and Vicia faba. Mutat Res 537:109-114

Yordanova RY, Christov KN, Popova LP (2004) Antioxidative enzymes in barley plants subjected to soil flooding. Environ Exp Bot 51(2):93-101

Zhang F, Wang Z, Dong J (2007) Effect of heavy metal stress on antioxidative enzymes and lipid peroxidation in leaves and roots of two mangrove plant seedlings (Kandelia candel and Bruguira gymnorrhiza). Chemosphere 67:44-50 